\title{
Enteric Campylobacter: Purging Its Secrets?
}

\author{
ELLEN CRUSHELL, SINEAD HARTY, FARHANA SHARIF, AND BILLY BOURKE \\ Children's Research Centre, Our Lady's Hospital for Sick Children, Department of Pediatrics, Conway \\ Institute of Biomolecular and Biomedical Research and Dublin Molecular Medicine Center, Univeristy \\ College Dublin, Dublin 12, Ireland.
}

\begin{abstract}
ABS
Campylobacterial infections are the most common cause of
bacterial enterocolitis in humans. Among children, especially in developing countries, Campylobacter infections can cause severe life-threatening diarrheal disease. Although usually associated with a benign outcome in the developed world, the burden of illness posed by Campylobacter infections is enormous, and serious neurologic sequelae also can occur. For a variety of reasons our understanding of the molecular and cellular pathogenesis of Campylobacter infection has lagged far behind that of
\end{abstract}

other enteric pathogens. However, recent completion of the genome sequence of Campylobacter jejuni promises to open up the Campylobacter research field with the prospect of developing novel therapeutic and preventive strategies. (Pediatr Res 55: 3-12, 2004)

Abbreviations
GBS, Guillain-Barré syndrome
CDT, cytolethal distending toxin

After its successful isolation from stool in the 1970s, Campylobacter jejuni rapidly has become the most commonly recognized cause of bacterial gastroenteritis in humans. Fastidious culture requirements (1) and difficulties with early attempts at genetic modification have hampered progress in understanding this organism compared with other enteric pathogens such as Escherichia coli and Salmonella species. Currently, however, there is a renaissance of interest in Campylobacter. In particular, the 1.64 million nucleotides of the $C$. jejuni genome have been sequenced, providing an impetus for further research into this pathogen and its unique virulence and survival properties (2). Although C. jejuni is the best-studied member of the Campylobacter genus, there exists a number of other Campylobacter species of relevance to human disease. This review focuses on the current state of our understanding of human enteric campylobacters, with particular emphasis on the recent progress in molecular genetic and pathogenesis research in this area.

\section{MICROBIOLOGY}

Campylobacter (Greek "curved rod") organisms are Gramnegative, spiral, flagellated rods that have a characteristic rapid

Received January 17, 2003; accepted August 8, 2003.

Correspondence: Billy Bourke, M.D., FRCPI, Children's Research Centre, Our Lady's Hospital for Sick Children, Crumlin, Dublin 12, Ireland; e-mail: billy.bourke@ucd.ie

DOI: 10.1203/01.PDR.0000099794.06260.71 darting motility on microscopy. Campylobacters have fastidious culture requirements, and the routine culture of these organisms from stool has been developed relatively recently (1). Campylobacters are strictly microaerophilic, requiring 5 to $10 \%$ ambient oxygen, and do not grow in air. Some Campylobacter species including $C$. jejuni take up a coccal shape when exposed to atmospheric oxygen.

The family Campylobacteraceae (including Campylobacter and Arcobacter) continues to evolve. Fourteen Campylobacter species have been validated, and novel members continue to appear (3). C. fetus, the type species of the genus, is a common cause of abortion and infectious infertility among sheep and cattle, while rarely causing disease in humans. Traditionally, $C$. jejuni and $C$. coli are recognized as human enteropathogens. In addition, $C$. upsaliensis is now increasingly accepted as causing diarrheal disease, particularly in children (4-6).

\section{HISTORIC PERSPECTIVES}

Campylobacters are probably unique among enteric pathogens as almost a century elapsed between the first reports of the organism and the development of routine techniques for the culture of Campylobacter from stools. The earliest record of this organism dates back to 1886 when Escherich (7) described organisms resembling campylobacters ("vibrionen") in the intestinal contents from 16 of 17 children who had died of diarrheal disease. Thereafter, there appeared a number of arti- 
cles in German describing "nonculturable" spiral bacteria in dysenteric disease (8). The first successful culture of Campylobacter was from ovine abortuses by McFadyean and Stockman in 1913 (9). In 1938 Levy (10) isolated Campylobacterlike organisms from the blood of 13 patients affected during a large milkborne outbreak of diarrheal disease in the United States. Campylobacter subsequently was cultured from the blood of three pregnant women in France in 1947 (11). King $(12,13)$ labeled these spiral bacteria "related vibrios" (because of their apparent similarity to Vibrio cholera) and described them in great detail. King recognized that the organism likely was more important as a cause of diarrhea of unknown etiology than previously was recognized.

Early isolates of Campylobacter were from blood and other normally sterile sites. Stool cultures were unsuccessful because of overgrowth of coliforms. As culture methods were refined, attempts to isolate the organism succeeded, and recognition of the importance of C. jejuni in diarrheal disease led rapidly to the introduction of routine methods for its isolation from stool $(1,14-16)$.

\section{EPIDEMIOLOGY}

In the United States, it is estimated that 2.4 million cases of campylobacteriosis occur annually. Although accounting for only $5 \%$ of estimated food-related deaths, campylobacters are responsible for approximately $17 \%$ of hospitalizations resulting from foodborne infections (17). The global economic burden of Campylobacter infections and Campylobacterinduced GBS is substantial. In the United States alone it has been estimated that human Campylobacter illnesses cost up to $\$ 8$ billion annually (18). This figure likely represents an underestimate, as it does not include other indirect costs such as physical and psychological liability associated with Campylobacter-induced GBS.

In view of potential under-reporting, attempts have been made to estimate the true incidence of intestinal infections (19). In a recent community- and general practice-based study in the United Kingdom, it was found that for every isolate of Campylobacter reported to the National Surveillance Scheme, 7.6 were unreported. By extrapolating, it was estimated that the total number of cases of C. jejuni in 1999 in the United Kingdom was 450,000 . This figure agrees closely with other community-based studies in both the United Kingdom and United States that estimate a population-based incidence of approximately $1 \%(20,21)$.

The incidence of Campylobacter infection among children is age related with a higher incidence among younger children in the developing world whereas in industrialized countries the incidence is highest in older children. In a study of American children Campylobacter was isolated in $4.8 \%$ and $8.3 \%$ of diarrheal stools in those aged 1-4 y and 10-19 y, respectively (21). In developing countries, Campylobacter infection is hyperendemic owing to poor sanitation and close contact with animals in the home (22-24). In these countries, C. jejuni infection is very common in early childhood, with five to 10 separate infections commonly occurring in the first $2 \mathrm{y}$ of life (25-27). For example, in a report from Tanzania, $22 \%$ of stool samples from children aged $<18$ mo with diarrhea grew Campylobacter (23), whereas in an Egyptian cohort, children younger than $3 \mathrm{y}$ had an incidence of 0.6 episodes of Campylobacter diarrhea per year (28). By late childhood, however, few symptomatic infections occur, a decline that correlates with the appearance of specific serum $\operatorname{IgA}$ antibodies to $C$. jejuni (29).

Although Campylobacter enteritis generally is considered a benign self-limiting disease, there is significant morbidity and mortality, even in developed countries. A recent report from the U.S. Centers for Disease Control and Prevention estimates Campylobacter infection causes 124 deaths annually in the United States (17). Mortality rates in developing countries are much higher; $13 \%$ of Campylobacter enteritis in Egyptian children younger than $3 \mathrm{y}$ is characterized by severe dehydration (28). The mortality risk from infection is highest at the extremes of age and in those with an underlying disease process.

\section{TRAVELERS' DIARRHEA}

Campylobacters are a leading cause of travelers' diarrhea $(30,31)$. For example, Petruccelli et al. (32) found Campylobacter in $41 \%$ of stools from military personnel with travelers' diarrhea. The prevalence of Campylobacter-associated travelers' diarrhea shows seasonal variation. For example, Mattila et al. (33) implicated $C$. jejuni in $30 \%$ of diarrheal episodes among Finnish travelers to Morocco during winter, whereas $7 \%$ of cases were ascribed to this organism during autumn. Similarly, C. jejuni enteritis among American students in Mexico is commoner in winter (34). The clinical symptoms of $C$. jejuni appear to be determined by the country of origin of the traveler, suggesting that the expression of the illness may relate to prior exposure and immunity rather than to local strains of the bacteria (35).

\section{RESERVOIRS AND TRANSMISSION OF INFECTION}

Campylobacter enterocolitis is considered to be a zoonosis. Enteric campylobacters are regarded as normal flora in many mammals and birds. The ability of these bacteria to grow at $42^{\circ} \mathrm{C}$ likely reflects their adaptation to the avian gut. Campylobacter appears to permanently colonize the gastrointestinal tract of birds with few noticeable ill effects and only occasionally is diarrhea observed with Campylobacter infection in young animals (36). Shedding of campylobacters by birds [very high Campylobacter carriage rates have been reported among geese and ducks $(37,38)$, among others] causes contamination of waterways, and, as campylobacters can survive in water for weeks, open waters may then act as a source of infection for domestic animals.

Although waterborne and milkborne outbreaks of human $C$. jejuni infection may occur (39-42), Campylobacter infections in humans are usually sporadic. Raw milk and poultry are the main sources of Campylobacter entering the food chain. Up to $6 \%$ of bulked raw milk samples in the United Kingdom yield campylobacters (43). Cross-contamination of milk occurs from feces during milking or from Campylobacter mastitis $(44,45)$, and failed pasteurization also has been associated with out- 
breaks of infection $(41,46,47)$. Studies have shown very high rates of Campylobacter contamination among supermarket chickens (48). Liver and offal from other species also may harbor Campylobacter, whereas contamination of red meat is much less frequent $(49,50)$. Although traditional cooking methods kill Campylobacter, these organisms may survive fondue and barbecue cooking (51).

Direct transmission from animals accounts for a minority of human infections occurring mainly among people who work in close contact with animals or their products (52). Campylobacter carriage is common among asymptomatic dogs and cats. However, prevalence rates are very variable, being highest among immature animals (up to $50 \%$ in some studies) that are strays or living in kennels and lowest $(<2 \%)$ among adult animals living in households. Animal-to-human transmission of $C$. jejuni has been validated by the finding of genotypically identical strains in a household pet and an infant with sepsis (53). Zoonotic infection with Campylobacter usually occurs in young children who have had close contact with puppies or kittens with diarrhea. Having a household pet with diarrhea and daily contact with a dog has been estimated to increase substantially the risk of becoming ill with Campylobacter compared with unexposed controls (54). In addition, dogs and cats may be important sources of infection with Campylobacter species other than $C$. jejuni (51), for example, C. upsaliensis is particularly common among these household animals (55-57).

It appears that the risk of direct transmission of Campylobacter from person-to-person is low, and secondary cases in outbreaks are not common. However, infants born to mothers who are excreting campylobacters are at risk of infection at the time of birth, usually resulting in self-limiting neonatal enteritis associated with bloody diarrhea $(58,59)$. There also have been outbreaks of campylobacteriosis in neonatal units; vehicles including communally used rectal thermometers and asymptomatic person-to-person spread have been implicated $(60,61)$.

\section{PATHOGENESIS}

Campylobacter in the postgenomic era. Adhesion, invasion, toxin production, and subversion of host cell processes are themes common to the virulence machinery of many enteric prokaryotic pathogens (Table 1). Our understanding of the roles of these virulence processes in Campylobacter pathogenesis is relatively poorly developed compared with other enteric pathogens. Potential reasons underlying this relative paucity of understanding of Campylobacter pathogenesis include initial difficulties at molecular genetic manipulations, interstrain variability in virulence, and lack of an effective animal model of human enteric infection. However, there now appears to be a renewal of interest in Campylobacter infections, resulting in novel and important insights into basic research on these organisms and the attraction of new investigators to the field.

In a landmark paper, Parkhill et al. (2) recently described the completion of the $C$. jejuni NCTC11168 genome sequence. It would be difficult to overemphasise the importance of the completion and deposition in the public domain of this 1.6-
Table 1. Campylobacter virulence factors

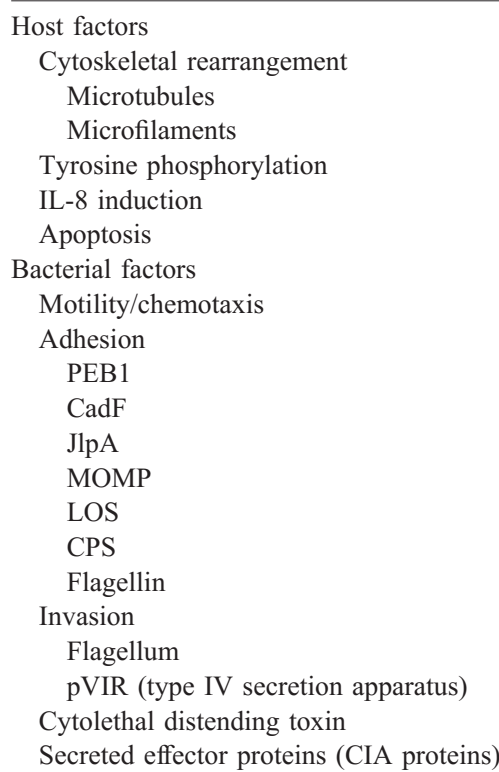

See text for discussion of individual virulence factors.

MOMP, major outer membrane protein; LOS, lipooligosaccharide; CPS, capsular polysaccharide.

megabase sequence. In the first instance, availability of the genome has provided immediate clarification of a number of previously unresolved questions and contentious issues surrounding Campylobacter research. For example, there are no pilus structures encoded on the chromosome, and the only toxin genes identifiable are the $c d t$ genes (2). In addition, a number of unexpected findings from the completed $C$. jejuni sequence have prompted research endeavors in novel directions. In particular, the identification of a substantial number of homopolymeric tracts indicates the potential importance of slipped-strand mispairing and consequent phase variation to the virulence and survival of this organism (62).

Flagella. The flagella of $C$. jejuni are composed of proteins, FlaA and FlaB, encoded by two genes sharing a high degree of sequence homology (63). Disruptions in FlaA, in particular, reduce motility and markedly reduce the ability of the organism to colonize the gastrointestinal tract (63). However, flagella are also important for invasion of (and to a lesser extent adherence to) host cells, as aflagellate organisms show markedly reduced internalization into host cells in vitro (63).

Invasion. C. jejuni has been shown within human colonic epithelial cells taken both from infected humans and macaque monkeys (64). In addition, the invasiveness of this organism has been studied in a variety of cell lines, in particular human intestine-derived Caco-2 and INT 407 cells $(64,65)$. Although some isolates of $C$. jejuni, such as the well characterized 81-176 strain, are highly invasive in these experimental models, many isolates show low levels of host cell entry in vitro (65). It has been suggested that campylobacters may not efficiently enter the host cell via the apical membrane, and recent evidence supports the contention that $C$. jejuni preferentially enters polarized epithelial cells via the basolateral membrane (66). In support of this model, there exists evidence both for paracellular passage (66) and M-cell transcytosis $(64,65)$ of $C$. jejuni. 
Many invasive pathogens subvert host cytoskeletal structures as part of the pathogenic process. The highly invasive $C$. jejuni 81-176 demonstrates microtubule-dependent invasion, and also appears to rely on microtubule motors for uptake and intracellular motility $(62,67)$ (Fig. 1). Nonetheless, most strains of C. jejuni demonstrate microfilament-dependent or

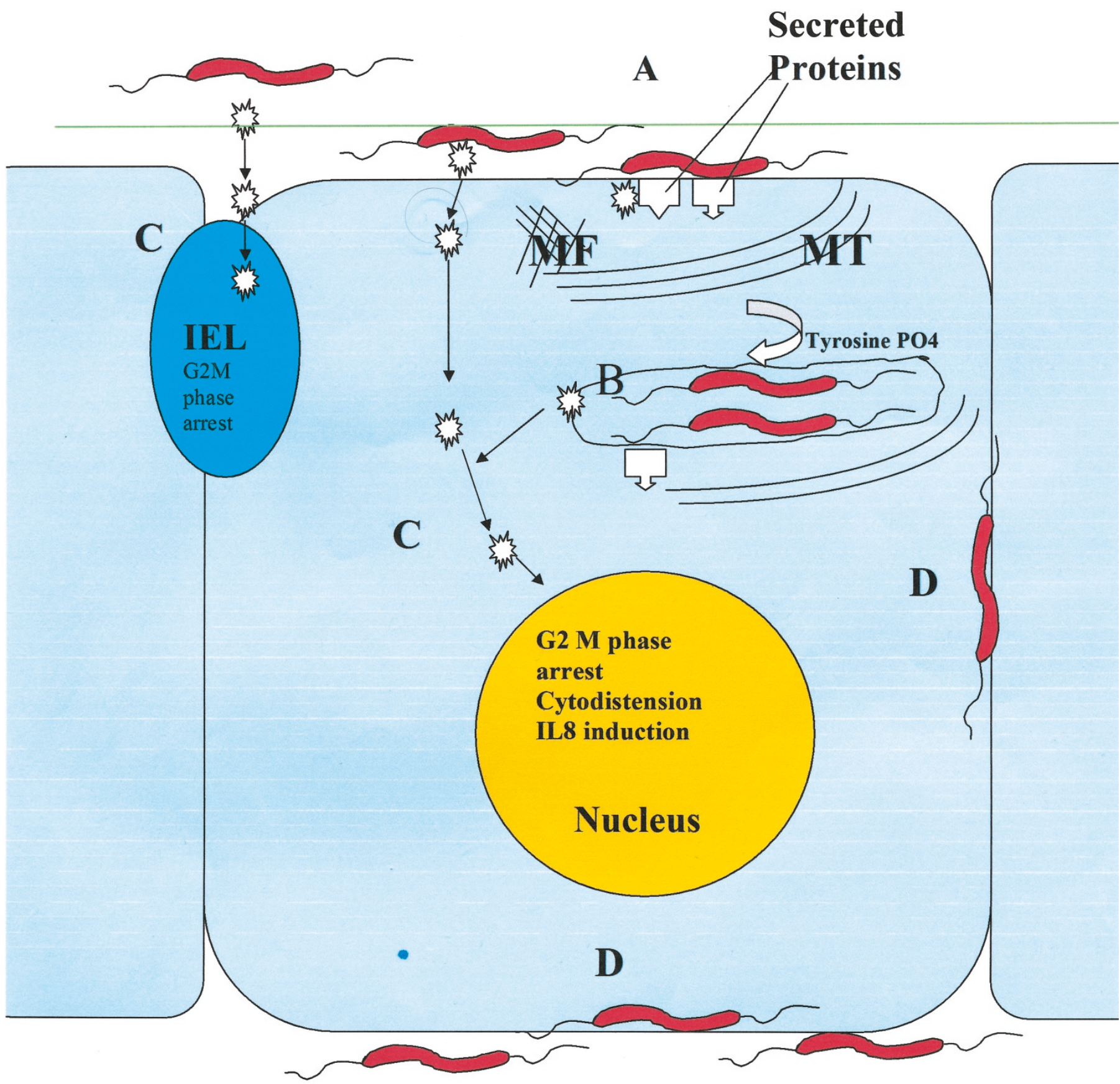

Figure 1. A speculative model of $C$. jejuni interaction with host intestinal epithelial cells is presented. A, after access to, and motility within, the mucus layer, C. jejuni organisms attach to the apical surface of host intestinal cells. Current evidence suggests that the attachment process is mediated via a number of adhesin-receptor interactions. Putative adhesins include major outer membrane protein $(M O M P)$, lipooligosacharride, capsular polysacharride, CadF, JlpA, and PEB1 (see text). C. jejuni is one of only a handful of bacteria that appear to subvert host microtubule structures to gain entry to and move within host cells. Bacterial secreted proteins may be involved in recruiting host cell structures, including microtubules (MT), microtubule motors (e.g. dynein), and microfilaments $(M F)$, as well as inducing host cell protein tyrosine phosphorylation or activation of trimeric G proteins to effect bacterial entry to the cell and possible subsequent intracytoplasmic motility. $B$, bacteria appear to survive and replicate, at least to some extent, within intracytoplasmic vacuoles. How bacteria achieve access to adjacent cells is unknown. $C$, CDT has DNase activity (mediated by CdtB). It may act directly on enterocytes to induce host cell cycle arrest, distension, and proinflammatory cytokine induction. Alternatively (or in addition), CDT may act on immune cells, such as intraepithelial lymphocytes (IEL), to cause cell cycle arrest. Whether CDT accesses cells after release from bacteria before cell contact, at the time of attachment, or after internalization is unknown. $D$, there also exist data to support paracellular migration of bacteria, possibly through disrupted tight junctions, or M-cell transcytosis with access of bacteria to the basolateral mebrane of the enterocytes (66). MT, microtubules; MF, microfilaments; IEL, intraepithelial lymphocytes. cytolethal distending toxin (B subunit) secreted effector proteins including CiaB. 
microfilament/microtubule-dependent invasiveness (68). Little is known of the invasiveness of other enteric campylobacters. However, a recent report implicates both of these cytoskeletal structures during cellular uptake of C. upsaliensis (69).

Adhesion. A variety of putative $C$. jejuni adhesions have been identified. These include PEB1 (a homolog of Gramnegative $\mathrm{ABC}$ transport systems) (70), CadF (a fibronectinbinding protein) (71), major outer membrane protein (72), and lipooligosaccharide (73). Recently, a novel surface-exposed lipoprotein specific to $C$. jejuni has been implicated in host cell adherence (74). As with other aspects of Campylobacter virulence, determining the precise contribution of these potential virulence factors to human disease has been frustrated by the lack of a suitable and widely accessible animal model of infection. However, from available data, it would appear that adherence of $C$. jejuni to host cells is a multistep process, involving both specific and nonspecific adhesin-receptor interactions. Intriguingly, the $C$. jejuni genome sequence has identified the presence in this organism of capsular polysaccharide biosynthesis genes. This heretofore unrecognized structure is common among $C$. jejuni strains, and appears to form the basis of the Penner serotyping system for this species (75). Recent publications also suggest a role for this polysaccharide structure in virulence $(75,76)$, and the presence of hypervariable genes within the locus with the potential for phase variation (77) is notable in this respect.

Toxin production. Historically, a variety of toxic activities have been attributed to $C$. jejuni. This subject has been extensively reviewed elsewhere (78). However, CDT is the only verified Campylobacter toxin identified to date, a situation unlikely to change unless one or more of the open reading frames of unknown function encoded on the genomic sequence (or on an extrachromasomal element) are shown to encode a toxin-inducing protein. Work on CDT from campylobacters and other organisms recently has led to a rapid advancement in our understanding of the cellular effects of these proteins in vitro (75-85). It is now clear that CdtB is the active moiety of the Cdt $\mathrm{ABC}$ complex. The $c d t B$ gene product has DNase activity (86). It appears that $\mathrm{Cdt} A$ and $\mathrm{CdtC}$ interact with $\mathrm{CdtB}$ to form a tripartite CDT holotoxin necessary for the delivery of the enzymatically active subunit, $\mathrm{CdtB}$ (86). Affected epithelial cells undergo cytodistension and cell cycle arrest in $\mathrm{G}_{2} / \mathrm{M}$ phase $(79,84)$. Cell cycle arrest also occurs in $\mathrm{T}$ lymphocytes exposed to CDT-mediating sonicates from C. upsaliensis (83). It is not yet clear what role CDT plays in infection in vivo. However, it may contribute more to immune-modulation and invasiveness (81) than directly to inducing diarrhea.

Secreted proteins and chemokine induction. Subversion of host cell processes by targeting bacterial products to host cytoplasm during the infection process is an increasingly recognized prokaryotic virulence mechanism. Using confocal microscopy, Konkel et al. (87) have identified a C. jejuni protein, $\mathrm{CiaB}$, that appears to enter host cells during the invasion process. Isogenic ciaB-negative mutants were shown to be deficient in secretion of a number of bacterial proteins. The genome of $C$. jejuni 11168 encodes a flagellar export system. However, there is no evidence for the presence of a typical type III secretory apparatus - the so-called molecular syringe- implicated in delivering bacterial proteins to the host cell in other infections. Recently, homologs of a type IV secretory apparatus have been identified on a large plasmid (pVir) in $C$. jejuni 81-176 (88). Type IV systems, for example the cag pathogenicity island of $H$. pylori, also are used by bacterial pathogens to inject substrates into the cytosol of target cells. $C$. jejuni $\mathrm{pVir}$ is a $37-\mathrm{kb}$ plasmid that has been shown to harbor 54 predicted open reading frames (89). Mutations in some of the plasmid-encoded genes reduced invasion compared with the parental strain in vitro. However, transfer of the plasmid to the sequenced strain, NCTC 11168 , did not increase the relatively low invasiveness of this isolate. Clearly, with only $10 \%$ of 58 fresh clinical $C$. jejuni isolates harboring the plasmid-encoded VirB11 gene (88), pVir is not responsible for all C. jejuniinduced pathogenic effects.

C. jejuni enterocolitis involves activation of the local immune response. IL-8 is a potent chemokine involved in, among other things, neutrophil attraction. IL-8 can be induced by $C$. jejuni (85). Current evidence implicates both direct interaction of $C$. jejuni with host cells and CDT elaboration in the induction of IL-8 $(82,85)$. It appears that uptake of bacteria into host cells is required for high levels of IL-8 induction in vitro.

It is apparent that there has been a rapid expansion in our understanding of $C$. jejuni pathogenesis (Fig. 1). Recently, successful and efficient transposon mutagenesis $(90,91)$ has breached one of the early barriers to the explication of $C$. jejuni molecular pathogenesis. Together with the genomic sequence, which will provide the cornerstone for powerful novel techniques such as microarray and protein expression methodologies, these developments herald a renaissance period for Campylobacter research that can be expected to continue for some time.

\section{CLINICAL MANIFESTATIONS}

Gastrointestinal. The clinical presentation of patients with C. jejuni infection differs between developing and industrialized countries. Variations in bacterial virulence or host immune response each may play a role in these different phenotypic expressions of disease (35). In the developing world, infection can be asymptomatic or there may be mild noninflammatory diarrhea, predominantly affecting young children $(23,27)$. In the industrialized world, the commonest illness caused by $C$. jejuni infection is a self-limiting gastrointestinal illness. Affected individuals experience varying degrees of diarrhea, which may range from a few loose stools to profuse watery diarrhea causing dehydration. Often, although probably not as frequently as previously thought (42), the stools are bloody and may contain mucus or pus. The diarrhea is accompanied by crampy abdominal pain that usually begins within $1-5 \mathrm{~d}$ of exposure (42). Systemic upset is common with fever [and febrile convulsions in vulnerable children (92)], malaise, and headache. These symptoms sometimes precede the onset of abdominal symptoms. Vomiting also may occur. Symptoms usually resolve within a week. The convalescent excretion of the organism lasts a mean of $16 \mathrm{~d}$. Infants excrete the organisms for longer than older children (mean, $14 \mathrm{~d}$ in infants versus $8 \mathrm{~d}$ in 1 - to 5 -y-olds) (27). Carriage may be prolonged 
with $4 \%$ of untreated children continuing to excrete the organism for 6 wk (93). Relapse occurs in up to $20 \%$ of patients, but symptoms are usually milder than in the original illness.

Recent evidence suggests a much higher incidence of irritable bowel syndrome among patients after an episode of Campylobacter enteritis than in patients without an antecedent history of enteric infection (94). Campylobacter also occasionally has been implicated as the cause of nonenteric gastrointestinal disease, as illustrated in Table 2. However, most of these complications are very uncommon or have been reported in adults with a contributing underlying disease process. Infection with enteric campylobacters, other than $C$. jejuni (C. coli and $C$. upsaliensis), results in a similar disease spectrum to that caused by $C$. jejuni. However, watery diarrhea appears to be more commonly associated with $C$. upsaliensis infection than is inflammatory diarrhea $(4,95)$.

Host response. After ingestion of campylobacters, colonization of the mucous blanket and adhesion to the intestinal cell surface occurs. The normal absorptive function of the intestinal cell is disrupted directly by cell invasion and toxin production and indirectly after the initiation of an inflammatory response. The clinical presentation is dependent on many factors, including possible variations in virulence among $C$. jejuni bacteria (96) and also the extent and nature of the host response, which will determine the degree to which the intestinal epithelium is damaged and the amount of fluid secreted. The host response appears to be largely determined by immunity acquired

Table 2. Spectrum of disease caused by Campylobacter spp.

\begin{tabular}{l} 
Gastrointestinal \\
Enteritis \\
Toxic megacolon and perforation \\
Hepatitis \\
Pancreatitis \\
Cholecystitis \\
Gastric ulceration \\
Peritonitis \\
Splenic rupture \\
Rheumatologic \\
Reactive arthritis \\
Reiters syndrome \\
Septic arthritis \\
Vertebral osteomyelitis \\
Henoch-Schönlein purpura \\
Neurologic \\
Guillain-Barré syndrome \\
Meningitis \\
Meningoencephalitis \\
Skin \\
Cellulitis \\
Skin eruption \\
Abscess \\
Lung \\
Empyema \\
Pneumonia \\
Intravascular \\
Bacteremia \\
Endocarditis \\
Thrombophlebitis \\
Hemolytic uremic syndrome \\
Aneurysm \\
\hline
\end{tabular}

through prior infection. Infection of adult volunteers with $C$. jejuni produced an inflammatory illness with a serum antibody response (97). When these volunteers were rechallenged with the same strain, they were protected from illness but not from colonization (97). In developing countries recurrent early infections with Campylobacter strains leads to progressive immunity (with an age-related rise in specific immunoglobulins), which results in successively milder symptoms with each infection $(26,29,30)$.

Immunocompromised hosts. Immunocompromised patients may have a severe, prolonged, or relapsing illness with extraintestinal manifestations, and accompanying bacteremia is more frequent $(98-100)$. In patients with immunoglobulin deficiencies, the organism can take years to eradicate (101), indicating that the humoral immune response is important in combating these infections. The incidence of Campylobacter infection is 40-100 times greater in persons with AIDS than in the background population (102), and non-C. jejuni species are found in this group (103). In a study from Spain the incidence of Campylobacter bacteremia among AIDS patients was $0.8 \%$ (99). Bacteremia was associated with low $\mathrm{CD}^{+}$lymphocyte counts and normal neutrophil counts. In patients with advanced HIV or AIDS, bacteremia is persistent or recurrent, despite appropriate antimicrobial treatment. Occurrence of Campylobacter infections in AIDS patients may herald a marked deterioration in immune status and limited patient survival (102).

Extraintestinal diseases and GBS. C. jejuni causes abortion and premature birth in humans. Maternal $C$. jejuni bacteremia is associated with fetoplacental involvement, resulting in premature labor, perinatal sepsis, and neonatal meningitis. Fetal and neonatal mortality rate may be as high as $80 \%$, particularly if infection occurs before the third trimester of pregnancy (104, 105). Other extraintestinal manifestations (Table 2) are rare.

Longer-term sequelae of $C$. jejuni include reactive arthritis, commonly affecting the knee and other peripheral joints, and Reiters syndrome, comprising the triad of asymmetric arthritis, urethritis, and ophthalmitis in HLA B-27-positive patients (106). GBS, an acute progressive neuropathy characterized by paralysis, pain, muscular weakness, and distal sensory loss, is a more sinister complication of Campylobacter enteritis. With the marked reduction in incidence of poliomyelitis, GBS is now the leading cause of acute flaccid paralysis in the world and is thought to occur in 1 in 1000 cases of $C$. jejuni enteritis (107). C. jejuni is the most common antecedent of GBS $(108-110)$; serologic and culture evidence indicates that 30 to $40 \%$ of patients with GBS have had infection with $C$. jejuni between $10 \mathrm{~d}$ and $2 \mathrm{wk}$ before the onset of neurologic symptoms. A seasonal epidemic form of GBS termed acute motor axonal neuropathy is observed mainly in northern China and is particularly associated with evidence of antecedent $C$. jejuni infection $(111,112)$.

A detailed review of the immunopathogenesis of GBS is beyond the scope of this review. The reader is referred to a recent extensive review by Hadden and Gregson (113). However, current evidence suggests that both host and bacterial factors contribute to the development of GBS after $C$. jejuni infection. Several observations point to microorganism-related 
factors. In Japan 52 to $77 \%$ of patients with C. jejuniassociated GBS were shown to have Penner serotype O:19, an unusual strain among enteritis isolates (accounting for approximately $3 \%$ of $C$. jejuni enteritis) (114-116). In South Africa, $9(53 \%)$ of 17 children admitted to an intensive care unit with GBS had evidence of $C$. jejuni infection and all isolates were Penner serotype 0:41. This particular serotype was isolated from only 12 (including the nine GBS isolates) of 7119 isolates $(<0.002 \%)$ of $C$. jejuni in that laboratory during the same time period, thus supporting a causal relationship between rare variants of this organism and $\operatorname{GBS}(117,118)$. Interestingly, these findings have not been reproduced in U.K. studies, implying that the GBS-inducing properties of $C$. jejuni may not be solely related to Penner serotype (110).

Miller-Fisher syndrome, a variant of GBS characterized by ophthalmoplegia, ataxia, and areflexia, also is associated with C. jejuni. During the acute phase of this illness, IgG antibodies to GQ1b ganglioside (a ganglioside found abundantly in ocular motor nerves) are present in $90 \%$ of Miller-Fisher syndrome patients, implicating antigenic mimicry between $C$. jejuni and myelin sheath epitopes in the pathogenesis of this less common neuropathy (119).

Management. As C. jejuni infection usually is self-limited, in most cases there is no rationale for antimicrobial treatment. Management is usually supportive with administration of fluid and electrolyte therapy, when necessary. There is evidence to suggest that erythromycin or azithromycin given early in the course of the infection shortens the duration of illness and prevents relapse (93). With these treatments, the organism usually is eradicated from the stool within 2 or $3 \mathrm{~d}$. The recommended duration of treatment is 5 to $7 \mathrm{~d}$. Bacteremic strains of Campylobacter are usually sensitive to aminoglycosides, meropenem, and imipenem. Antimicrobial treatment should be considered in children with immunodeficiencies, in severe cases with much bloody diarrhea, and when the infection is ongoing after $1 \mathrm{wk}(120)$.

Antibiotic resistance among $C$. jejuni has become a serious worldwide problem. Ciprofloxacin has been commonly used to treat Campylobacter infections. However, fluoroquinolones have become less effective as resistance has increased dramatically (121). Quinolone resistance is thought to have emerged because of the widespread use of this class of antibiotics on poultry farms in Europe and the United States $(122,123)$. The link to animal agriculture was first demonstrated in Holland by Endtz et al. (122), where the prevalence of quinolone resistance rates among isolates from poultry products increased from 0 to $14 \%$ between 1982 and 1989, coinciding with the increasing use of fluoroquinolones in veterinary medicine. During the same time frame, resistant human isolates increased from 0 to $11 \%$. Similarly, Smith et al. (123) demonstrated a significant increase in quinolone resistance among human Campylobacter isolates between 1996 and 1998 that was temporally associated with the licensure of fluoroquinolones for use in poultry in the United States. Conversely, quinolone resistance is not a problem in Australia, where these antibiotics have been prohibited from use in food-producing animals. In contrast, erythromycin resistance rates remain low among human isolates $(<5 \%)(124-126)$, and erythromycin is the anti- biotic of choice for the treatment of Campylobacter gastroenteritis $(123,124)$. To date, ciprofloxacin has been commonly used for traveler's diarrhea, although Sanders et al. (127) found in vitro resistance to quinolones in $96 \%$ of Campylobacter isolates from U.S. military personnel in Thailand, thereby highlighting the problem with empiric treatment in areas with high quinolone resistance rates.

For patients with GBS, referral to a tertiary center may be necessary, as a proportion of patients will need ventilatory assistance and plasmapheresis. Multiple stool samples (or rectal swabs) at the time of presentation are necessary if antecedent $C$. jejuni is to be detected (114). Serologic studies may also be necessary as the median onset of neuropathic symptoms is $9 \mathrm{~d}$ after the onset of diarrhea (110). Treatment studies have shown that both plasma exchange (128) and i.v. immunoglobulin $(129,130)$ significantly reduce the duration of GBS.

\section{PREVENTION}

As the primary source of Campylobacter infection in humans is foodstuffs, particularly poultry, prevention should be aimed at reducing the infection level among poultry houses. Biosecurity measures on poultry farms have improved, with increased usage of disinfectant foot dips and hygiene barriers at the entrances to poultry houses. However, once Campylobacter infection enters a poultry house, all birds become carriers very quickly (131).

The high levels of campylobacters on chicken carcasses can be reduced effectively by irradiation; however, there is public resistance to this method of disinfection. In the kitchen, crosscontamination of Campylobacter from chicken carcasses occurs rapidly and widely (49). Hot water and detergent have been shown to remove Campylobacter from kitchen surfaces (132). In addition, the use of chlorine-based disinfectant significantly reduces kitchen surface contamination rates with Campylobacter when compared with hot water and detergent or no cleaning (133). Adequate cooking of poultry meat is essential, and fondue and barbecuing may not be sufficient to kill the campylobacters. Public education programs are important in the prevention of infection acquired through poor hygiene and food preparation techniques. However, a recent insightful commentary on the area clearly points to substantial deficits in our understanding of the risk to human health posed by domestic Campylobacter contamination levels (49).

Human milk contains secretory IgA antibodies to a Campylobacter antigen and breastfed infants are less likely to develop Campylobacter-associated diarrhea than their nonbreast-fed counterparts (92). The development of a vaccine against Campylobacter has been hindered because until recently there was a lack of understanding of the basic virulence mechanisms and antigenic complexity of these organisms and also because of the theoretical risk of triggering GBS. Nonetheless, an oral, killed, whole-cell vaccine has been shown to be safe and effective in animal studies (134).

\section{CONCLUSIONS}

Campylobacters are major causes of human disease worldwide. A new era of Campylobacter research has been heralded 
by the recent completion of the genomic sequence of $C$. jejuni, and substantial progress now has been made in our understanding of how these organisms mediate disease in humans. Transcriptomics, proteomics, and efficient mass mutagenesis techniques are set to rapidly expand our knowledge of the molecular and cellular microbiology of Campylobacter infection. There is a pressing need for the development of easily accessible, reproducible, and biologically relevant models of enteric and neurologic diseases caused by these organisms so that we may devise effective therapeutic and preventive strategies against human Campylobacter infection and its consequences.

\section{REFERENCES}

1. Skirrow MB 1977 Campylobacter enteritis: a "new" disease. BMJ 2:9-11

2. Parkhill J, Wren BW, Mungall K, Ketley JM, Churcher C, Basham D, Chillingworth T, Davies RM, Feltwell T, Holyrod S, Jagels K, Karlyshev AV, Moule S, Pallen MJ, Penn CW, Quail MA, Rajandream MA, Rutherford KM, van Vliet AH, Whitehead S, Barrell BG 2000 The genome sequence of the food-borne pathogen Campylobacter jejuni reveals hypervariable sequences. Nature 403:665-668

3. Lawson AJ, On SL, Logan JM, Stanley J 2001 Campylobacter hominis sp. nov., from the human gastrointestinal tract. Int J Syst Evol Microbiol 51:651-660

4. Bourke B, Chan VL, Sherman P 1998 Campylobacter upsaliensis: waiting in the wings. Clin Microbiol Rev 11:440-449

5. Goossens H, Giesendorf BA, Vandamme P, Vlaes L, Van den Borre C, Koeken A, Quint WG, Blomme W, Hanicq P, Koster DS 1995 Investigation of an outbreak of Campylobacter upsaliensis in day care centers in Brussels: analysis of relationships among isolates by phenotypic and genotypic typing methods. J Infect Dis 172:12981305

6. Goossens H, Vlaes L, De Boeck M, Pot B, Kersters K, Levy J, De Mol P, Butzler JP, Vandamme P 1990 Is "Campylobacter upsaliensis" an unrecognised cause of human diarrhoea? Lancet 335:584-586

7. Escherich T 1886 Beitraege zur Kenntniss der Darmbacterien. III. Ueber das Vorkommen von Vibrionen im Darmcanal und den Stuhlgaengen der Saeuglinge. [Articles adding to the knowledge of intestinal bacteria. III. On the existence of vibrios in the intestines and feces of babies] Muench Med Wochenschr 33: 815-817, $833-835$

8. Kist M 1986 Who discovered Campylobacter jejuni/coli? A review of hitherto disregarded literature. Zentralbl Bakteriol Mikrobiol Hyg 261:177-186

9. McFadyean J, Stockman S 1913 Report of the Departmental Committee appointed by the Board of Agriculture and Fisheries to inquire into Epizootic Abortion. Part III. Abortion in Sheep. HMSO, London

10. Levy AJ 1947 A gastro-enteritis outbreak probably due to a bovine strain of vibrio. Yale J Biol Med 18:243-258

11. Vinzent R, Dumas J, Picard N 1947 Septicemie grave au cours de la grossesse, due a un vibrion. Bull Acad Natl Med 131:90-92

12. King EO 1957 Human infection with Vibrio fetus and a closely related vibrio. J Infect Dis 101:119-128

13. King EO 1962 The laboratory recognition of Vibrio fetus and closely related vibrio isolated from cases of human vibriosis. Ann NY Acad Sci 98:700-711

14. Cooper IA, Slee KJ 1971 Human infection by Vibrio fetus. Med J Aust 1:1263-1267

15. Dekeyser P, Gossuin-Detrain M, Butzler JP, Sternon J 1972 Acute enteritis due to related vibrio: first positive stool cultures. J Infect Dis 125:390-392

16. Butzler JP, Dekeyser P, Detrain M, Dehaen F 1973 Related vibrio in stools. J Pediatr 82:493-495

17. Mead PS, Slutsker L, Dietz V, McCaig LF, Bresee JS, Shapiro C, Griffin PM, Tauxe RV 1999 Food-related illness and death in the United States. Emerg Infect Dis 1999 5:607-625

18. Buzby JC, Allos BM, Roberts T 1997 The economic burden of Campylobacterassociated Guillain-Barré syndrome. J Infect Dis 176:S192-S197

19. Wheeler JG, Sethi D, Cowden JM, Wall PG, Rodrigues LC, Tompkins DS, Hudson MJ, Roderick PJ 1999 Study of infectious intestinal disease in England: rates in the community, presenting to general practice, and reported to national surveillance. BMJ 318:1046-1050

20. Kendall EJ, Tanner EI 1982 Campylobacter enteritis in general practice. J Hyg (Lond) $88: 155-163$

21. Tauxe R 1992 Epidemiology of Campylobacter jejuni infections in the United States and other industrialized nations. In: Nachamkin I, Blaser MJ, Tompkins L (eds) Campylobacter jejuni: Current Status and Future Trends. American Society for Microbiology, New York, pp 9-19

22. Uysal G, Dogru U, Aysev D, Karabiber N 1997 Campylobacter jejuni gastroenteritis in Turkish children. Infection 25:159-162

23. Lindblom GB, Ahren C, Changalucha J, Gabone R, Kaijser B, Nilsson LA, Sjogren E, Svennerholm AM, Temu M 1995 Campylobacter jejuni/coli and enterotoxigenic Escherichia coli (ETEC) in faeces from children and adults in Tanzania. Scand $\mathrm{J}$ Infect Dis 27:589-593

24. Gedlu E, Aseffa A 1996 Campylobacter enteritis among children in north-west Ethiopia: a 1-year prospective study. Ann Trop Paediatr 16:207-212
25. Calva JJ, Ruiz-Palacios GM, Lopez-Vidal AB, Ramos A, Bojalil R 1988 Cohort study of intestinal infection with Campylobacter in Mexican children. Lancet 1:503-506

26. Taylor DN, Perlman DM, Echeverria PD, Lexomboon U, Blaser MJ 1993 Campylobacter immunity and quantitative excretion rates in Thai children. J Infect Dis 168:754-758

27. Taylor DN, Echeverria P, Pitarangsi C, Seriwatana J, Bodhidatta L, Blaser MJ 1988 Influence of strain characteristics and immunity on the epidemiology of Campylobacter infections in Thailand. J Clin Microbiol 26:863-868

28. Rao MR, Naficy AB, Savarino SJ, Abu-Elyazeed R, Wierzba TF, Peruski LF, Abdel-Messih I, Frenck R, Clemens JD 2001 Pathogenicity and convalescent excretion of Campylobacter in rural Egyptian children. Am J Epidemiol 154:166173

29. Blaser MJ, Black RE, Duncan DJ, Amer J 1985 Campylobacter jejuni-specific serum antibodies are elevated in healthy Bangladeshi children. J Clin Microbiol 21:164-167

30. Taylor DN 1992 Campylobacter infections in developing countries. In: Nachamkin I, Blaser MJ, Tompkins LS, (eds) Campylobacter jejuni: Current Status and Future Trends. American Society for Microbiology, New York, pp 20-30

31. Rasrinaul L, Suthienkul O, Echeverria PD, Taylor DN, Seriwatana J, Bangtrakulnonth A, Lexomboon U 1988 Foods as a source of enteropathogens causing childhood diarrhea in Thailand. Am J Trop Med Hyg 39:97-102

32. Petruccelli BP, Murphy GS, Sanchez JL, Walz S, DeFraites R, Gelnett J, Haberberger RL, Echeverria P, Taylor DN 1992 Treatment of traveler's diarrhea with ciprofloxacin and loperamide. J Infect Dis 165:557-560

33. Mattila L, Siitonen A, Kyronseppa H, Simula I, Oksanen P, Stenvik M, Salo P, Peltola H 1992 Seasonal variation in etiology of travelers' diarrhea. J Infect Dis 165:385-388

34. Ericsson CD, DuPont HL, Mathewson III 1995 Epidemiologic observations on diarrhea developing in U.S. and Mexican students living in Guadalajara, Mexico. J Travel Med 2:6-10

35. Ketley JM 1997 Pathogenesis of enteric infection by Campylobacter. Microbiology $143: 5-21$

36. Newell DG 2001 Animal models of Campylobacter jejuni colonization and disease and the lessons to be learned from similar Helicobacter pylori models. Symp Ser Soc Appl Microbiol 30:57S-67S

37. Aydin F, Atabay HI, Akan M 2001 The isolation and characterization of Campylobacter jejuni subsp. jejuni from domestic geese (Anser anser). J Appl Microbiol 90:637-642

38. Prescott JF, Bruin-Mosch CW 1981 Carriage of Campylobacter jejuni in healthy and diarrheic animals. Am J Vet Res 42:164-165

39. Sacks JJ, Lieb S, Baldy LM, Berta S, Patton CM, White MC, Bigler WJ, Witte JJ 1986 Epidemic campylobacteriosis associated with a community water supply. Am J Public Health 76:424-428

40. Taylor DN, McDermott KT, Little JR, Wells JG, Blaser MJ 1983 Campylobacter enteritis from untreated water in the Rocky Mountains. Ann Intern Med 99:38-40

41. Jones PH, Willis AT, Robinson DA, Skirrow MB, Josephs DS 1981 Campylobacter enteritis associated with the consumption of free school milk. J Hyg (Lond) 87:155-162

42. Blaser MJ, Sazie E, Williams LPJ 1987 The influence of immunity on raw milk-associated Campylobacter infection. JAMA 257:43-46

43. Humphrey TJ, Hart RJ 1988 Campylobacter and Salmonella contamination of unpasteurized cows' milk on sale to the public. J Appl Bacteriol 65:463-467

44. Waterman SC, Park RW, Bramley AJ 1984 A search for the source of Campylobacter jejuni in milk. J Hyg (Lond) 93:333-337

45. Hutchinson DN, Bolton FJ, Hinchliffe PM, Dawkins HC, Horsley SD, Jessop EG, Robertshaw PA, Counter DE 1985 Evidence of udder excretion of Campylobacter jejuni as the cause of milk-borne Campylobacter outbreak. J Hyg (Lond) 94:205215

46. Fahey T, Morgan D, Gunneburg C, Adak GK, Majid F, Kaczmarski E 1995 An outbreak of Campylobacter jejuni enteritis associated with failed milk pasteurisation. J Infect 31:137-143

47. Wallace JM 1980 Milk-associated Campylobacter infection. Health Bull (Edinb) 38:57-61

48. Simmons NA, Gibbs FJ 1979 Campylobacter spp. in oven-ready poultry. J Infect $1: 159-162$

49. Humphrey T 2001 The spread and persistence of Campylobacter and Salmonella in the domestic kitchen. J Infect 43:50-53

50. Kramer JM, Frost JA, Bolton FJ, Wareing DR 2000 Campylobacter contamination of raw meat and poultry at retail sale: identification of multiple types and comparison with isolates from human infection. J Food Prot 63:1654-1659

51. Kapperud G, Skjerve E, Bean NH, Ostroff SM, Lassen J 1992 Risk factors for sporadic Campylobacter infections: results of a case-control study in southeastern Norway. J Clin Microbiol 30:3117-3121

52. Jones DM, Robinson DA 1981 Occupational exposure to Campylobacter jejuni infection [letter]. Lancet 1:440-441

53. Wolfs TF, Duim B, Geelen SP, Rigter A, Thomson-Carter F, Fleer A, Wagenaar JA 2001 Neonatal sepsis by Campylobacter jejuni: genetically proven transmission from a household puppy. Clin Infect Dis 32:E97-E99

54. Adak GK, Cowden JM, Nicholas S, Evans HS 1995 The Public Health Laboratory Service national case-control study of primary indigenous sporadic cases of Campylobacter infection. Epidemiol Infect 115: 15-22

55. Shen Z, Feng Y, Dewhirst FE, Fox JG 2001 Coinfection of enteric Helicobacter spp. and Campylobacter spp. in cats. J Clin Microbiol 39:2166-2172 
56. Byrne C, Doherty D, Mooney A, Byrne M, Woodward D, Johnson W, Rodgers F, Bourke B 2001 Basis of the superiority of cefoperazone amphotericin teicoplanin for isolating Campylobacter upsaliensis from stools. J Clin Microbiol 39:2713-2716

57. Baker J, Barton MD, Lanser J 1999 Campylobacter species in cats and dogs in South Australia. Aust Vet J 77:662-666

58. Shimizu T, Ezaki Y, Tamura H, Kobayashi H, Shibamoto T, Nakai Y, Nagano T, Niinobu K, Ro G, Risai T 1986 Studies on Campylobacter and Salmonella in feces of pregnant women and newborn infants [Abstract in English]. Nippon Sanka Fujinka Gakkai Zasshi 38:493-498

59. Karmali MA, Norrish B, Lior H, Heyes B, Monteath A, Montgomery H 1984 Campylobacter enterocolitis in a neonatal nursery. J Infect Dis 149:874-877

60. Hershkowici S, Barak M, Cohen A, Montag J 1987 An outbreak of Campylobacter jejuni infection in a neonatal intensive care unit. J Hosp Infect 9:54-59

61. Morooka T, Takeo H, Yasumoto S, Mimatsu T, Yukitake K, Oda T 1992 Nosocomial meningitis due to Campylobacter fetus subspecies fetus in a neonatal intensive care unit. Acta Paediatr Jpn 34:530-533

62. Bourke B 2002 Campylobacter infection: small bowel and colon. Curr Opin Gastroenterol 18:4-9

63. Wassenaar TM, Blaser MJ 1999 Pathophysiology of Campylobacter jejuni infections of humans. Microb Infect 1:1023-1033

64. Woolridge KG, Ketley JM 1997 Campylobacter-host cell interactions. Trends Microbiol 5:96-102

65. Kopecko DJ, Hu L, Zaal KJ 2001 Campylobacter jejuni-microtubule-dependent invasion. Trends Microbiol 9:389-396

66. Monteville MR, Konkel ME 2002 Fibronectin-facilitated invasion of T84 eukaryotic cells by Campylobacter jejuni occurs preferentially at the basolateral cell surface. Infect Immun 70:6665-6671

67. Hu L, Kopecko DJ 1999 Campylobacter jejuni 81-176 associates with microtubules and dynein during invasion of human intestinal cells. Infect Immun 67:4171-4182

68. Biswas D, Itoh K, Sasakawa C 2000 Uptake pathways of clinical and healthy anima isolates of Campylobacter jejuni into INT-407 cells. FEMS Immunol Med Microbio 29:203-211

69. Mooney A, Byrne C, Clyne M, Johnson-Henry K, Sherman P, Bourke B 2003 Invasion of human epithelial cells by Campylobacter upsaliensis. Cell Microbiol 5:835-847

70. Pei Z, Blaser MJ 1993 PEB1, the major cell-binding factor of Campylobacter jejuni, is a homolog of the binding component in gram-negative nutrient transport systems. J Biol Chem 268:18717-18725

71. Konkel ME, Garvis SG, Tipton SL, Anderson DEJ, Cieplak WJ 1997 Identification and molecular cloning of a gene encoding a fibronectin-binding protein (CadF) from Campylobacter jejuni. Mol Microbiol 24:953-963

72. Moser I, Schroeder W, Salnikow J 1997 Campylobacter jejuni major outer membrane protein and a 59-kDa protein are involved in binding to fibronectin and INT 407 cell membranes. FEMS Microbiol Lett 157:233-238

73. Fry BN, Feng S, Chen YY, Newell DG, Coloe PJ, Korolik V 2000 The galE gene of Campylobacter jejuni is involved in lipopolysaccharide synthesis and virulence. Infect Immun 68:2594-2601

74. Jin S, Joe A, Lynett J, Hani EK, Sherman P, Chan VL 2001 JlpA, a novel surface-exposed lipoprotein specific to Campylobacter jejuni, mediates adherence to host epithelial cells. Mol Microbiol 39:1225-1236

75. Karlyshev AV, Wren BW 2001 Detection and initial characterization of novel capsular polysaccharide among diverse Campylobacter jejuni strains using alcian blue dye. J Clin Microbiol 39:279-284

76. Bacon DJ, Szymanski CM, Burr DH, Silver RP, Alm RA, Guerry P 2001 A phase-variable capsule is involved in virulence of Campylobacter jejuni 81-176. Mol Microbiol 40:769-777

77. Karlyshev AV, Linton D, Gregson NA, Lastovica AJ, Wren BW 2000 Genetic and biochemical evidence of a Campylobacter jejuni capsular polysaccharide that accounts for Penner serotype specificity. Mol Microbiol 35:529-541

78. Pickett CL 2000 Campylobacter toxins and their role in pathogenesis In: Nachamkin I, Blaser MJ (eds) Campylobacter. ASM Press, Washington, pp 179-190

79. Elwell CA, Dreyfus LA 2000 DNase I homologous residues in CdtB are critical for cytolethal distending toxin-mediated cell cycle arrest. Mol Microbiol 37:952-963

80. Cortes-Bratti X, Chaves-Olarte E, Lagergard T, Thelestam M 2000 Cellular internalization of cytolethal distending toxin from Haemophilus ducreyi. Infect Immun 68:6903-691

81. Purdy D, Buswell CM, Hodgson AE, McAlpine K, Henderson I, Leach SA 2000 Characterisation of cytolethal distending toxin (CDT) mutants of Campylobacter jejuni. J Med Microbiol 49:473-479

82. Hickey TE, McVeigh AL, Scott DA, Michielutti RE, Bixby A, Carroll SA, Bourgeois AL, Guerry P 2000 Campylobacter jejuni cytolethal distending toxin mediates release of interleukin-8 from intestinal epithelial cells. Infect Immun 68:6535-6541

83. Mooney A, Clyne M, Curran T, Doherty D, Kilmartin B, Bourke B 2001 Campylobacter upsaliensis exerts a cytolethal distending toxin effect on HeLa cells and $\mathrm{T}$ lymphocytes. Microbiology 147:735-743

84. Lara-Tejero M, Galan JE 2000 A bacterial toxin that controls cell cycle progression as a deoxyribonuclease I-like protein. Science 290:354-357

85. Hickey TE, Baqar S, Bourgeois AL, Ewing CP, Guerry P 1999 Campylobacter jejuni-stimulated secretion of interleukin- 8 by INT407 cells. Infect Immun 67:88-93

86. Lara-Tejero M, Galan JE $2001 \mathrm{CdtA}, \mathrm{CdtB}$, and CdtC form a tripartite complex that is required for cytolethal distending toxin activity. Infect Immun 69:4358-4365

87. Konkel ME, Kim BJ, Rivera-Amill V, Garvis SG 1999 Bacterial secreted protein are required for the internaliztion of Campylobacter jejuni into cultured mammalian cells. Mol Microbiol 32:691-701
88. Bacon DJ, Alm RA, Burr DH, Hu L, Kopecko DJ, Ewing CP, Trust TJ, Guerry P 2000 Involvement of a plasmid in virulence of Campylobacter jejuni 81-176. Infect Immun 68:4384-4390

89. Bacon DJ, Alm RA, Hu L, Hickey TE, Ewing CP, Batchelor RA, Trust TJ, Guerry P 2002 DNA sequence and mutational analyses of the p Vir plasmid of Campylobacter jejuni 81-176. Infect Immun 70:6242-6250

90. Colegio OR, Griffin TJ, Grindley ND, Galan JE 2001 In vitro transposition system for efficient generation of random mutants of Campylobacter jejuni. J Bacteriol 183:2384-2388

91. Hendrixson DR, Akerley BJ, DiRita VJ 2001 Transposon mutagenesis of Campylobacter jejuni identifies a bipartite energy taxis system required for motility. Mol Microbiol 40:214-224

92. Ruiz-Palacios GM, Calva JJ, Pickering LK 1990 Protection of breast-fed infants against Campylobacter diarrhea by antibodies in human milk. J Pediatr 116:707-713

93. Karmali MA, Fleming PC 1979 Campylobacter enteritis in children. J Pediatr 94:527-533

94. Rodriguez LA, Ruigomez A 1999 Increased risk of irritable bowel syndrome after bacterial gastroenteritis: cohort study. BMJ 318:565-566

95. Jimenez SG, Heine RG, Ward PB, Robins-Browne RM 1999 Campylobacter upsaliensis gastroenteritis in childhood. Pediatr Infect Dis J 18:988-992

96. Everest PH, Goossens H, Butzler JP, Lloyd D, Knutton S, Ketley JM, Williams PH 1992 Differentiated Caco-2 cells as a model for enteric invasion by Campylobacter jejuni and C. coli. J Med Microbiol 37:319-325

97. Black RE, Levine MM, Clements ML, Hughes TP, Blaser MJ 1988 Experimental Campylobacter jejuni infection in humans. J Infect Dis 157:472-479

98. Pigrau C, Bartolome R, Almirante B, Planes AM, Gavalda J, Pahissa A 1997 Bacteremia due to Campylobacter species: clinical findings and antimicrobial susceptibility patterns. Clin Infect Dis 25:1414-1420

99. Pigrau C, Almirante B, Pahissa A, Bartolome R 1996 Campylobacter spp. bacteremia in AIDS patients [letter]. J Acquir Immune Defic Syndr Hum Retroviro 12:93-95

100. Slutsker L, Altekruse SF, Swerdlow DL 1998 Foodborne diseases: emerging pathogens and trends. Infect Dis Clin North Am 12:199-216

101. Autenrieth IB, Schuster V, Ewald J, Harmsen D, Kreth HW 1996 An unusual case of refractory Campylobacter jejuni infection in a patient with X-linked agammaglobulinemia: successful combined therapy with maternal plasma and ciprofloxacin Clin Infect Dis 23:526-531

102. Sorvillo FJ, Lieb LE, Waterman SH 1991 Incidence of campylobacteriosis among patients with AIDS in Los Angeles County. J Acquir Immune Defic Syndr 4:598-602

103. Snijders F, Kuijper EJ, de Wever B, van der Hoek L, Danner SA, Dankert J 1997 Prevalence of Campylobacter-associated diarrhea among patients infected with human immunodeficiency virus. Clin Infect Dis 24:1107-1113

104. Simor AE, Ferro S 1990 Campylobacter jejuni infection occurring during pregnancy. Eur J Clin Microbiol Infect Dis 9:142-144

105. Simor AE, Karmali MA, Jadavji T, Roscoe M 1986 Abortion and perinatal sepsis associated with Campylobacter infection. Rev Infect Dis 8:397-402

106. Leung FY, Littlejohn GO, Bombardier C 1980 Reiter's syndrome after Campylobacter jejuni enteritis. Arthritis Rheum 23:948-950

107. Nachamkin I, Allos BM, Ho T 1998 Campylobacter species and Guillain-Barré syndrome Clin Microbiol Rev 11:555-567

108. Jacobs BC, Rothbarth PH, van der Meche FG, Herbrink P, Schmitz PI, de Klerk MA, van Doorn PA 1998 The spectrum of antecedent infections in Guillain-Barre syndrome: a case-control study. Neurology 51:1110-1115

109. Mishu B, Ilyas AA, Koski CL, Vriesendorp F, Cook SD, Mithen FA, Blaser MJ 1993 Serologic evidence of previous Campylobacter jejuni infection in patients with the Guillain-Barré syndrome. Ann Intern Med 118:947-953

110. Rees JH, Soudain SE, Gregson NA, Hughes RA 1995 Campylobacter jejun infection and Guillain-Barré syndrome. N Engl J Med 333:1374-1379

111. McKhann GM, Cornblath DR, Griffin JW, Ho TW, Li CY, Jiang Z, Wu HS, Zhaori G, Liu Y, Jou LP 1993 Acute motor axonal neuropathy: a frequent cause of acute flaccid paralysis in China. Ann Neurol 33:333-342

112. Ho TW, Mishu B, Li CY, Gao CY, Cornblath DR, Griffin JW, Asbury AK, Blaser MJ, McKhann GM 1995 Guillain-Barré syndrome in northern China: relationship to Campylobacter jejuni infection and anti-glycolipid antibodies. Brain 118:597-605

113. Hadden RD, Gregson NA 2001 Guillain-Barré syndrome and Campylobacter jejun infection. J Appl Microbiol 90:145S-154S

114. Kuroki S, Saida T, Nukina M, Haruta T, Yoshioka M, Kobayashi Y, Nakanishi H 1993 Campylobacter jejuni strains from patients with Guillain-Barré syndrome belong mostly to Penner serogroup 19 and contain beta- $N$-acetylglucosamine residues. Ann Neurol 33:243-247

115. Yuki N, Takahashi M, Tagawa Y, Kashiwase K, Tadokoro K, Saito K 1997 Association of Campylobacter jejuni serotype with antiganglioside antibody in Guillain-Barré syndrome and Fisher's syndrome. Ann Neurol 42:28-33

116. Saida T, Kuroki S, Hao Q, Nishimura M, Nukina M, Obayashi H 1997 Campy lobacter jejuni isolates from Japanese patients with Guillain-Barré syndrome. J Infect Dis 176(suppl 2):S129-S134

117. Lastovica AJ, Goddard EA, Argent AC 1997 Guillain-Barré syndrome in South Africa associated with Campylobacter jejuni O:41 strains. J Infect Dis 176(suppl 2):S139-S143

118. Goddard EA, Lastovica AJ, Argent AC 1997 Campylobacter 0:41 isolation in Guillain-Barré syndrome. Arch Dis Child 76:526-528

119. Neisser A, Bernheimer H, Berger T, Moran AP, Schwerer B 1997 Serum antibodies against gangliosides and Campylobacter jejuni lipopolysaccharides in Miller Fisher syndrome. Infect Immun 65:4038-4042

120. Blaser MJ 1997 Epidemiologic and clinical features of Campylobacter jejun infections. J Infect Dis 176(suppl 2):S103-S105 
121. Engberg J, Aarestrup FM, Taylor DE, Gerner-Smidt P, Nachamkin I 2001 Quinolone and macrolide resistance in Campylobacter jejuni and C. coli: resistance mechanisms and trends in human isolates. Emerg Infect Dis 7:24-34

122. Endtz HP, Ruijs GJ, van Klingeren B, Jansen WH, van der Reyden T, Mouton RP 1991 Quinolone resistance in Campylobacter isolated from man and poultry following the introduction of fluoroquinolones in veterinary medicine. J Antimicrob Chemother 27:199-208

123. Smith KE, Besser JM, Hedberg CW, Leano FT Bender JB, Wicklund JH, Johnson BP, Moore KA, Osterholm MT 1999 Quinolone-resistant Campylobacter jejuni infections in Minnesota, 1992-1998. N Engl J Med 340:1525-1532

124. Nachamkin I, Ung H, Li M 2002 Increasing fluoroquinolone resistance in Campy lobacter jejuni, Pennyslvania USA, 1982-2001. Emerg Infect Dis 8:1501-1503

125. Talsma E, Goettsch WG, Nieste HL, Schrijnemakers PM, Sprenger MJ 1999 Resistance in Campylobacter species: increased resistance to fluoroquinolones and seasonal variation. Clin Infect Dis 29:845-848

126. Lucey B, Feurer C, Greer P, Moloney P, Cryan B, Fanning S 2000 Antimicrobial resistance profiling and DNA amplification fingerprinting (DAF) of thermophilic Campylobacter spp. in human, poultry and porcine samples from the Cork region of Ireland. J Appl Microbiol 89:727-734

127. Sanders JW, Isenbarger DW, Walz SE, Pang LW, Scott DA, Tamminga C, Oyofo BA, Hewitson WC, Sanchez JL, Pitarangsi C, Echeverria P, Tribble DR 2002 An observational clinic-based study of diarrheal illness in deployed United States military personnel in Thailand: presentation and outcome of Campylobacter infection. Am J Trop Med Hyg 67:533-538

128. French Cooperative Group on Plasma Exchange in Guillain-Barré syndrome 1987 Efficiency of plasma exchange in Guillain-Barré syndrome: role of replacement fluids. Ann Neurol 22:753-761

129. Plasma Exchange/Sandoglobulin Guillain-Barré Syndrome Trial Group 1997 Randomised trial of plasma exchange, intravenous immunoglobulin, and combined treatments in Guillain-Barré syndrome. Lancet 349:225-230

130. Asbury AK 2000 New concepts of Guillain-Barré syndrome. J Child Neuro 15:183-191

131. Pattison M 2001 Practical intervention strategies for Campylobacter. J Appl Microbiol 90(suppl):121S-125S

132. Dawkins HC, Bolton FJ, Hutchinson DN 1984 A study of the spread of Campylobacter jejuni in four large kitchens. J Hyg (Lond) 92:357-364

133. Cogan TA, Bloomfield SF, Humphrey TJ 1999 The effectiveness of hygiene procedures for prevention of cross-contamination from chicken carcases in the domestic kitchen. Lett Appl Microbiol 29:354-358

134. Scott DA 1997 Vaccines against Campylobacter jejuni. J Infect Dis 176(suppl 2):S183-S188 